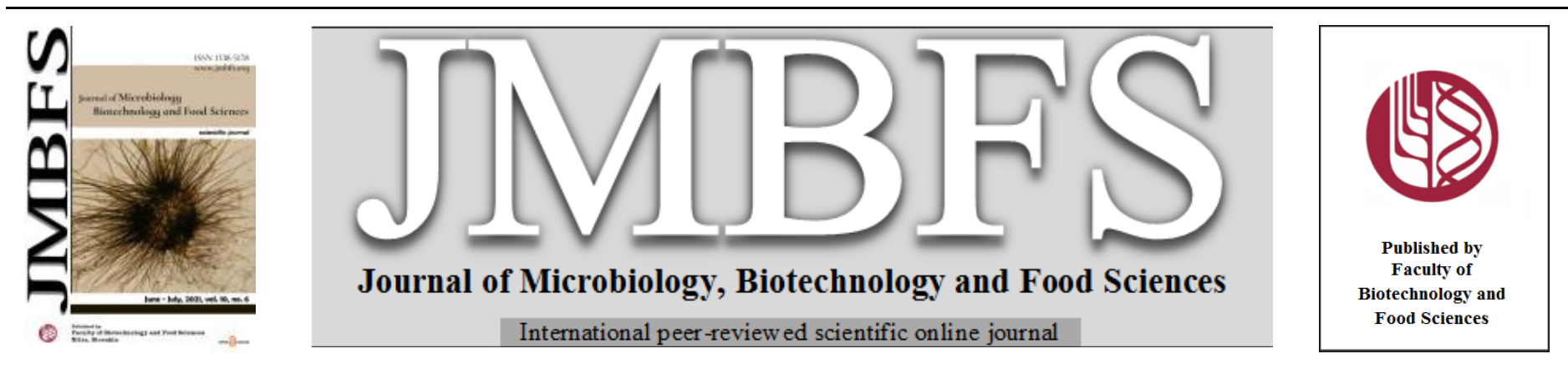

\title{
SIGHTS TO AUTHENTICATION AND ADULTERATION OF THE COFFEE IN GLOBAL ASPECT
}

\author{
Jozef Čurlej ${ }^{1 *}$, Alica Bobkovál, Peter Zajác ${ }^{l}$, Jozef Čapla ${ }^{l}$, Lukáš Hleba ${ }^{2}$ \\ Address(es): \\ ${ }^{1}$ Slovak University of Agriculture, Department of Hygiene and Safety, Tr. A. Hlinku 2, 949 76, Nitra, Slovakia. \\ ${ }^{2}$ Slovak University of Agriculture, Department of Microbiology, Tr. A. Hlinku 2, 949 76, Nitra, Slovakia.
}

*Corresponding author: jozef.curlej@uniag.sk

https://doi.org/10.15414/jmbfs.4793

\section{ARTICLE INFO}

Received 11.1.2021

Revised 22. 4. 2021

Accepted 5. 5. 2021

Published 1. 6. 2021

Regular article

OPEN $\partial_{\text {ACCESS }}$

\begin{abstract}
Coffee presents a valuable food product for several reasons, covering areas like a source of health benefits substances for the human body, brain energizing/stimulating product and its social aspect raising from coffee consumption. This study aims to summarise the most common practices used in coffee adulteration and the methods focused to confirm the authenticity of the coffee, the quality, and price determinants according to a place of origin and/or selection between Robusta versus Arabica coffee beans. Nowadays, several scientific approaches are used for this purpose, based on chemical or molecular analysis. Literature and the data presented in this article were collected from studies published in scientific journals. On the other hand, the article introduces how to protect customerls rights in the global coffee trade.
\end{abstract}

Keywords: Coffee, Adulteration, Authenticity, Methods

\section{INTRODUCTION}

Coffee constitutes a plant product high in economic value (Hariyadi $\boldsymbol{e t}$ al., 2020). Coffee can be used in modern marketing strategies (Berčík, et al., 2020a; Berčík, et al., 2020b). Drinking coffee has become part of our everyday culture. Coffee cultivation is devoted to over 50 countries in the world, located between latitudes 25 degrees North and 30 degrees South. Almost all of the world's coffee production is provided by two varieties, called 'Arabica' and 'Robusta' whereas the share of Arabica is more of the world's coffee harvest. Green (raw) coffee cannot be used to prepare coffee beverages, coffee beans must first be roasted (Diviš et al., 2019). Coffee presents one of the most popular traded products presented in two species under economical interest - Robusta (approx. $40 \%$ of the global production) and Arabica (approx. 60\% of the global production). There exist some differences that distinguish two species of their seed shape, morphology, and quality, cultivation requirements, as well as their brewing properties (van der Vossen et al., 2015). Arabica due to organoleptic properties are more preferred, characteristic by a higher acidity, and low bitterness. On the other hand, Robusta beans are harder compared to Arabica (Baker, 2016; Rubayiza and Meurens, 2005). Robusta coffee (Coffea canephora) leaves contain phytochemical compounds and have antioxidant and anti-diabetic effects (Widyastuti et al., 2020). Arabica coffee beans originated from 21 different regions of the world. Parameters of their moisture content, water extract, water extract in dry matter, dry matter, caffeine, and caffeine content in the dry matter were assessed by the Slovak Technical Standard (STN 580113-21:1991. Methods of coffee evaluation. Caffeine determination and STN 580114:2000. Methods for testing of coffee extracts and chicory). Dry matter content ranged from 98.64 to $99.07 \%$, the highest content was measured in a sample from Cuba. Minimum dry matter content was detected in coffee beans from Mexico. Caffeine in studied samples ranged from $10200 \mathrm{mg} . \mathrm{kg}-1$ to $13500 \mathrm{mg} . \mathrm{kg}-1$. The lowest caffeine content was determined in Panama coffee, the highest was found in the sample from Indonesia (Bobková et al., 2017).

Top players in the global coffee production and trade are south American, central African, and Asian producers (Rega and Ferranti, 2019). As coffee holds the first place in the list of most common frauded food (Lange, 2013), several techniques to reveal their attributes have been established.

Based on sensory evaluation (taste, smell, and sight), experts may be capable of discerning the origins and varieties of green and/or roasted beans. However, the accuracy and repeatability may vary depending on the sensory sensitivity towards specific coffee traits, physiological status of the evaluator, level of experiences, and/or environmental conditions. In this way, the discrimination will be more challenging for ground and brew samples, since the specific features associated with particular coffee beans may be reduced or lost during the grinding process (Wang et al., 2020). Apart from classical sensory approaches, the conventional methods, most widely used in laboratories have been established for adulteration identification of ground and roasted coffee, involving the use of optical and electron microscopy. The disadvantage of analyses based on microscopy is due to time consumption and subjective evaluation, producing conflicting results (Toci et al., 2016). Other laboratory techniques, therefore, have been used to provide more reliable analyses to identify possible adulteration, such as DNA-based techniques (Ferreira et al., 2016), chromatography (Martins et al., 2018), electrophoresis (Daniel et al., 2018), spectroscopy (Sezer et al., 2018), nearinfrared spectroscopy (Tolessa $\boldsymbol{e t}$ al. 2016), high resolution melting (Pereira $\boldsymbol{e}$ al., 2017). Fraudulent practices involve the substitution of Arabica coffee with cheaper Robusta, mixing of roasted ground coffee with undeclared materials (Toci et al., 2016). Furthermore, it can involve the quality of beans (considering species, geographical origin), as well as the addition of other substances (coffee husks, corn, barley, cocoa, wheat, brown sugar, soybean, triticale, acai, etc.) to coffee blends to make the production costs less expensive. Worldwide data on the topic of coffee adulteration is practically nonexistent, the main reason is caused by the domestic economic situation of each country. In Brazil, the world's largest coffee producer, an inspection revealed from 2400 analyzed brands 583 adulterated samples with maize, rye, husks, acai seeds, or brown sugar, which represents almost $25 \%$ of the national brands (Peixoto, 2009).

In conclusion, the key issues for control strategies, are determining the degree of dilution, geographic origin of the beans, specific adulterants, post-growth treatment, etc. to find, whether the product label claims are based on the truth. The present study is focused to summarize the most important facts about fraudulent practices in the field of coffee production and trade, based on relevant scientific information provided by various reports.

\section{Originality and declared quality}

Originality and quality have become the most important aspects for the coffee industry where various factors can affect the final product (Martins et al., 2018; Oliveira et al., 2015). An important aspect with a negative impact on the coffee industry is the presence of fraud approaches, presented by offering coffee/coffee products with the addition of low-cost materials and the presence of defective beans or even low-quality coffees or beans from different geographical regions in comparison to „facts” stated on the product label. Adulteration of the coffee product was first reported in the literature in 1851 (The Lancet, 1851). The high level of adulteration is considered a serious issue to the sustainable development of the coffee industry, for this purpose, some international organizations are 
involved in quality assurance of coffee worldwide, such as ICO, the Institute for Scientific Information on Coffee, and FAO (Cai et al., 2016; Oliveira et al., 2015). To achieve the authentication goals, the use of sensitive and specific analytical techniques is necessary to ensure the quality of coffees worldwide.

\section{Fraudulent practice}

\section{Diluents}

Graham et al. (1857) provided one of the earliest detection of fraudulent vegetable substances mixed with coffee by consideration of the sugar content color, and specific gravity of extracts, in addition to analysis for mineral (ash) content of the coffee sample in comparison with genuine coffees and possible vegetable adulterants. List of the most common diluents contains a large scale of substances such are: corn, rice, soybean, barley, wheat, triticale, acai palm seeds, cocoa, coffee husks (Domingues et al., 2014; Pauli et al., 2014). Their presence can be analyzed by the use of chemical (HPLC), physical (NIR), and molecula analysis (RT-PCR) (Burns and Walker, 2020), where real-time PCR is a powerful alternative to chemical methods for the identification of diluents (Ferreira et al., 2016). Adulteration by the common diluents insoluble (instant) coffee or in an extract from ground roast coffee can be detected by the ISO 23114:2011 criteria for authenticity (BS 5752-15, 1997) based on the maximum amounts of two indictor carbohydrates (total glucose and total xylose).

\section{Genotypic and Geographic Traits}

Numerous attempts have been done to identify the geographic origin of ground roast coffee samples by variations in trace elements or by molecular markers There are many important bioactive compounds in the coffee determined/affected by coffee species and grow conditions defined by soil and climate. Namely phenols (chlorogenic acids and derivatives), methylxanthines (mainly caffeine), trigonelline, nicotinic acid, diterpenes, and short-chain carboxylic acids (Jeszka-Skowron $\boldsymbol{e t}$ al., 2015). The significant differences in amounts of arabinose, galactose, and mannose extracted from coffee beans processed postharvest in different ways indicate that these sugars are not reliable species markers (Tarzia et al., 2010). As statements of geographic origin for modestly priced coffees have begun to appear on supermarket shelves, the authentication of a bean's geographic origin is now of consumer interest (Burns and Walker, 2020). In recent years, a few attempts have been done to identify the geographic origin of ground roast coffee by different compositions of trace elements (detected by: inductively coupled plasma-atomic emission spectroscopy, atomic adsorption, and neutron activation) or by molecular markers. This variation has been used to differentiate coffees grown in relatively small areas like Ethiopia (Mehari et al., 2016), Jamaica (Antoine et al., 2016), Brazil (Barbosa et al., 2014), Mexico (Muñiz-Valencia et al., 2014) - all the major coffee growing areas (Oliveira et al., 2015). Other scientific approaches as are Fourier transform infrared spectroscopy (FTIR) following solvent extraction permits the determination of molecular content variations to reveal country of origin: Africa and Asia (Fintello et al., 2017), Columbia, Costa Rica, Ethiopia, and Kenya (Wang et al., 2011), Brazil (Schievano et al., 2014). Metabolic analysis using NMR has been used to differentiate Arabica coffees grown in America, Africa, and Asia (Consonni et al., 2012). NIR spectroscopy has been used to identify the geographic origin of samples grown in Brazil (Marquetti $\boldsymbol{e}$ al. 2016). Potentially one of the most powerful signatures of geographic authenticity is the natural stable isotope ratios of the bio-elements (nitrogen, oxygen, carbon, hydrogen, and sulfur) (Carter et al., 2017). More successful geographic classifications appear to be possible by combining stable isotope ratios with elemental composition. Valentin and Watling claimed 97 and 100\% correct classification for the continent and within-continent country, respectively, and that the isotopic and elemental concentrations of green coffee beans remained largely unchanged on roasting (Valentin and Watling, 2013). At the present, there is no validated method to confirm the claim specific country of origin for coffee samples. As the normal trace element pattern for a given region may be disturbed using fertilizers, the use of molecular markers is advised (Burns and Walker, 2020).

\section{Substituents}

The price and rarity of certain types of coffee beans such as Blue Mountain Tanzanian Peaberry, and particularly Indonesian palm civet coffee (Kopi Luwak), leads to practice such substitution by cheaper beans (Burns and Walker, 2020; 50). In the same way, Arabica substituted by Robusta is commonly found as a practice to save money, but breaking the customer's rights for genuine products (Yener et al., 2015). Adulteration by Robusta in Arabica can be detected at levels above 1-2\% by the NMR method (Gunning $\boldsymbol{e t}$ al. 2018). For examination of mentioned above, tocopherols have been used as markers for Robusta/Arabica ratio in green or roasted coffee beans (Wermelinger et al., 2011). NIR is also a useful method for the same purpose (Bertone et al., 2016). The identification of Arabica and Robusta species in coffee samples is possible via the maker compounds kahweol and 16-OMC. The determination of 16-OMC by NMR has the advantage of speed, relative simplicity Deoxyribonucleic acid extraction and analysis from processed coffee beans was found as a useful laboratory tool for species identification (Martellossi et al., 2005) and has been developed as a rapid method to determine coffee species and the degree of adulteration by high-resolution melting (HRM) analysis on green or roasted coffee. For a more sensitive detection method chloroplastic, rather than nuclear genetic variations, were targeted between Coffea species (Combes et al., 2018). Using a metabolic approach, discriminan markers have been found to authenticate Kopi Luwak (Jumhawan et al., 2013; Jumhawan et al., 2015). No reports have been found whether the methods that can discriminate between authentic (wild or farmed) civet coffees and Arabica and Robusta samples that have been manufactured to appear as if they were civet coffee (Heo, 2014)

\section{The closer study of coffee chemical compounds}

\section{Homostachydrine}

Besides 16-O-methylcafestol, homostachydrine can be used as a more accurate indicator to quantify Robusta percentage in coffee blends (Servillo et al., 2016) In this field, Servillo et al. (2016) discovered that homostachydrine is considerably higher presented in Robusta $(31.0610 .0 \mathrm{mg} / \mathrm{kg}$ ) with a relatively narrow variation $(31.0610 .0 \mathrm{mg} / \mathrm{kg}$ ) than in Arabica beans $(1.560 .5 \mathrm{mg} / \mathrm{kg})$.

\section{Phenolic Acids}

The main phenolic acids in coffee are presented by chlorogenic acids (ferulic, caffeic, and p-coumaric acid), ranging from 3 to $12 \mathrm{~g} / 100 \mathrm{~g}$ of green coffee (Farah et al., 2005; Campa et al., 2005; Trugo and Macrae, 1984). Phenolic acid profiles of boiled-type coffee brews have been investigated by Górrnaś et al. (2016) for non-treated and decaffeinated beans from different species and regions, roasted to different degrees (Górnas et al. 2016). Phenolic acids in green and roasted coffee samples in majority representation are 3, 4, and 5caffeoylquinic acids, with the content in green beans being 2 to 6 times higher than the roasted samples. Moreover, higher content of phenolic acid has been found for Robusta as compared to Arabica (Farah et al., 2005; Campa et al., 2005; Trugo and Macrae, 1984). Total phenolic acid as the only marker is not enough to accurately distinguish Arabica and Robusta roasted coffee beans, considering the sensitivity to degree of roast and relatively small differences in concentration (Wang et al., 2020).

\section{Fatty acid and triacylglycerol}

The fatty acid profiles between coffee species are different, based on this statement is possible to detect Arabica and Robusta ratio in a mixture. Romano et al. (2014) concluded that total monounsaturated fatty acids concentration, linolenic acid (cis18:3n-3) concentration, the 18:0/cis18:1n-9 ratio, and the tota saturated fatty acid ratio are useful indicators for the determination of ArabicaRobusta blend proportions. Chemometric analysis by PCA and LDA achieved complete separation of Arabica and Robusta coffees, with linolenic, linoleic oleic, and myristic acids identified as the most differentiating descriptors (Martin et al., 2001). Alves et al. (2003) presented a similar technique to analyze the fatty acids of coffee samples from different botanical and geotechnica regions and designed the discrimination of Arabica and Robusta coffees both in green and roasted stages. The mentioned authors pointed to the affection of coffee's fatty acid profiles by roasting, specifically, trans-isomers increased sharply. This may be used as an indicator of roast processing conditions.

\section{Diterpenes}

Three main diterpenes found in the lipid fraction of coffees are presented by kahweol, cafestol, and 16-O-methylcafestol. Kahweol and cafestol are detected in higher level for Arabica coffees in comparison to Robusta, where a small amount of kahweol is found, along with 16-O-methylcafestol (stable substance during the roasting process), presented only in Robusta $(10-50 \mathrm{mg} / \mathrm{kg}$ ) but not in Arabica, thus it can be used to detect the adulteration of Arabica with Robusta in coffees, according to DIN 10779 (Schievano et al., 2014; DIN, 2011; Speer and Kölling-Speer, 2006)

\section{Carbohydrates}

Blanc et al. (1989) were the first who studied the sugar profiles of coffee. They screened more than a hundred instant coffees and extracts of roasted Arabica and Robusta coffees. They found, that pure soluble coffees (extraction condition is not an important factor), contained maximum levels of about $0.3 \%$ total xylose and sucrose and about $2 \%$ total glucose. Higher levels of total xylose indicate the presence of coffee husks. Furthermore, it was noticed that fucose can be used to detect coffee adulterated with soybean, corn as adulterant is causing higher concentrations of glucose and xylose (Daniel et al., 2018). 


\section{CONCLUSION}

This review is focused to prepare an overview of the most commonly used techniques for the authentication process of the coffee. The main proportion of used literature is focused on detection of Robusta in Arabica, as well as the detection of foreign components, and misrepresentation of the declared origin of coffee. According to knowledge published in the number of scientific valuable studies covering chemical, biological and physical approaches for identification of adulteration and coffee varieties, no sensitive and widely applicable method was available (Toci et al., 2016), thus it is necessary to develop a widely applicable and sensitive methodology that can address the various aspects of coffee adulteration. For instance, it covers detection of defective beans, discrimination between species, or identification of the presence of external agents. However, it has been possible to suggest approaches to deal with the key problems for the food control analyst, namely those of determining the degree of dilution, specific adulterant, geographic origin of the beans, and their species to test the truth of the labeled claims for a sample of roast ground coffee.

Acknowledgments: This work is partially supported by fundings from a grant VEGA 1/0734/20

\section{REFERENCES}

Alves, M.R., Casal, S., Oliveira, M.B.P.P., \& Ferreira, M.A. (2003) Discrimination between arabica and robusta coffee species based on their amino acid enantiomers," Journal of Agricultural and Food Chemistry, vol. 51, no. 22 pp. 6495-6501. https://doi.org/10.1021/jf034354w

Antoine, J.M.R., Hoo Fung, L.A., \& Grant, C.N. (2016) Geographic determination of the growing origins of Jamaican and international coffee using instrumental neutron activation analysis and other methods. J. Radioanal. Nucl. Chem., 309, no. 2, 525-534. https://doi.org/10.1007/s10967-015-4666-4

Baker, M. (2016) Arabica vs. Robusta comparison. Turkish Style Coffee. Available at: http://www.turkishstylegroundcoffee.com/coffeeeducation/ coffeeproduction/arabica-vs-robusta/ [accessed 2 May 2016]

Barbosa, R.M., Batisa, B.L., Varrique, R.M., Coelho, V.A., Campiglia, A.D., \& Barbosa, F., Jr. (2014) The use of advanced chemometric techniques and trace element levels for controlling the authenticity of organic coffee. Food Res. Int. 61, 246-251. https://doi.org/10.1016/j.foodres.2013.07.060

Berčík, J., Mravcová, A., Gálová, J., \& Mikláš, M. (2020a). The use of consumer neuroscience in aroma marketing of a service company. Potravinarstvo Slovak Journal of Food Sciences, 14, 1200-1210. https://doi.org/10.5219/1465

Berčík, J., Virágh, R., Kádeková, Z., \& Duchoňová, T. (2020b). Aroma marketing as a tool to increase turnover in a chosen business entity. Potravinarstvo Slovak Journal of Food Sciences, 14, 1161-1175. https://doi.org/10.5219/1475

Bertone, E., Venturelo, A., Giraudo, A., Pellegrino, G., Geobaldo, F. (2016) Simultaneous determination by NIR spectroscopy of the roasting degree and Arabic/Robusta ratio in roasted and ground coffee. Food Control, 59, 683-689. https://doi.org/10.1016/j.foodcont.2015.06.055

Blanc, M.B., Davis, G.E., Parchet, J.-M., \& Viani, R. (1989) Chromatographic profile of carbohydrates in commercial soluble coffees J. Agric. Food Chem., 37, 926-930. https://doi.org/10.1021/jf00088a022

Bobková, A., Fikselová, M., \& Šnirc, M. (2017). Selected parameters of arabica coffee quality affected by its geographical origin. Potravinarstvo Slovak Journa of Food Sciences, 11(1), 260-265. https://doi.org/10.5219/794

BS 5752-15:1997: Methods of Test for Coffee and Coffee Products Part 15: Instant Coffee: Determination of Free and Total Carbohydrate Contents by High Performance Anion- Exchange Chromatography, British Standards Institution, London, United Kingdom

Burns, D. T., Walker, M. J. 2020. Critical Review of Analytical and Bioanalytical Verification of the Authenticity of Coffee. Journal of AOAC International, 103 no. 2, 283-294. https://doi.org/10.5740/jaoacint.18-0392

Cai, T., Ting, H., Jin-lan, Z. (2016) Novel identification strategy for ground coffee adulteration based on UPLC-HRMS oligosaccharide profiling. Food Chem., 190, 1046-1049. https://doi.org/10.1016/j.foodchem.2015.06.084

Campa, C., Doulbeau, S., Dussert, S., Hamon, S., \& Noirot, M. (2005) Qualitative relationship between caffeine and chlorogenic acid contents among wild Coffea species Food Chem. vol. 93, no. 1, 135-139

Carter, J.F. (2017) in Food Forensics: Stable Isotopes as a Guide to Authenticity and Origin, J.F. Carter, \& L.A. Chesson (Eds), CRC Press, Boca Raton, FL, 169173. ISBN 9780367782085. https://doi.org/10.1201/9781315151649

Combes, M.C., Joët, T., \& Lashermes, P. (2018) Development of a rapid and efficient DNA-based method to detect and quantify adulterations in coffee (Arabica versus Robusta). Food Control, 88, 198-206. https://doi.org/10.1016/j.foodcont.2018.01.014

Consonni, R., Cagliani, L.R., \& Cogliati, C. (2012) NMR based geographical characterization of roasted coffee. Talanta, 88, 420-426. https://doi.org/10.1016/j.talanta.2011.11.010

Daniel, D., Lopes, F. S., Santos, V. B. dos, \& do Lago, C. L. (2018). Detection of coffee adulteration with soybean and corn by capillary electrophoresis-tandem mass spectrometry. Food Chem., 243,

$305-310$

https://doi.org/10.1016/j.foodchem.2017.09.140

DIN, Deutsches Institut fu“ r Normung e.V. Standard DIN 10779 (2011) Analysis of Coffee and Coffee Products-Determination of 16-O-Methyl Cafestol Conten of Roasted Coffee-HPLC Method, Berlin, Germany

Diviš, P., Pořizka, J., \& Kř́kala, J. (2019). The effect of coffee beans roasting on its chemical composition. Potravinarstvo Slovak Journal of Food Sciences, 13(1), 344-350. https://doi.org/10.5219/1062

Domingues, D.S., Pauli, E.D., de Abreu, J.E.M., Massura, F.W., Cristiano, V., Santos, M.J., Nixdorf, S.L. (2014) Detection of roasted and ground coffee adulteration by HPLC by amperometric and by postcolumn derivatization UVVis detection. Food Chem. 146, 353-362. https://doi.org/10.1016/j.foodchem.2013.09.066

Farah, A., De Paulis, T., Trugo, L.C., \& Martin, P.R. (2005) Effect of Roasting on the Formation of Chlorogenic Acid Lactones in Coffee J. Agric. Food Chem. vol. 53 , no. 5, 1505-1513

Ferreira, T., Farah, A., Oliveira, T.C., Lima, I.S., Vitório, F., Oliveira, E.M.M. (2016) Using real-time PCR as a tool for monitoring the authenticity of commercial coffees. Food Chem., 199, 433-438 https://doi.org/10.1016/j.foodchem.2015.12.045

Fintello, C., Forzato, C., Gasparini, A., Mammi, S., Navarini, L., \& Schievano, E. (2017) NMR quantification of 16-O-methylcafestol and kahweol in Coffea canephora var. robusta beans from different geographical origins. Food Control 75, 62-69. https://doi.org/10.1016/j.foodcont.2016.12.019

Górnas, P., Dwiecki, K., Siger, A., Tomaszewska-Gras, J., Michalak, M., \& Polewski, K. (2016) Contribution of phenolic acids isolated from green and roasted boiled-type coffee brews to total coffee antioxidant capacity Eur. Food Res. Technol. 242, 641-653

Graham, T., Stenhouse, J., Campbell, D. (1857) Chemical report on the mode of detecting vegetable substances mixed with coffee for the purposes of adulteration. Q. J. Chem. Soc., 9, 33-54.

Gunning, Y., Defernez, M., Watson, A.D., Beadman, N., Colquhoun, I.J., Le Gall, G., Philo, M., Garwood, H., Williamson, D., Davis, A.P., \& Kemsley, E.K. (2018) 16-O-methylcafestol is present in ground roast Arabica coffees: Implications for authenticity testing. Food Chem., 248, 52-60. https://doi.org/10.1016/j.foodchem.2017.12.034

Hariyadi, D. M., Tedja, C. A., Zubaidah, E., Yuwono, S. S., \& Fibrianto, K. (2020). Optimization of brewing time and temperature for caffeine and tannin levels in Dampit coffee leaf tea of Robusta (Coffea canephora) and Liberica (Coffea liberica). Potravinarstvo Slovak Journal of Food Sciences, 14, 58-68. https://doi.org/10.5219/1212

Heo, S.J. (2014) Preparation of Kopi Luwak Using Artificial Digestive Juices, K.R. Patent 2014089965 A 20140716

Jeszka-Skowron, M., Zgoła-Grześkowiak, A., Grześkowiak, T. (2015) Analytica methods applied for the characterisation and determination of bioactive compounds in coffee. Eur. Food Res. Technol., 240, 19-31. https://doi.org/10.1007/s00217-014-2356-Z

Jumhawan, U., Putri, S.P., Yusianto, Bamba, T., \& Fukusaki, E. (2015) Application of gas chromatography/flame ionization detector-based metabolite fingerprinting for authentication of Asian palm civet coffee (Kopi Luwak). $J$. Biosci. Bioeng., 120, 555-561. https://doi.org/10.1016/j.jbiosc.2015.03.005

Jumhawan, U., Putri, S.P., Yusianto, Marwani, E., Bamba, T., \& Fukusaki, E (2013) Selection of Discriminant Markers for Authentication of Asian Palm Civet Coffee (Kopi Luwak): A Metabolomics Approach. J. Agric. Food Chem., 61 7994-8001. https://doi.org/10.1021/jf401819s

Lange, E.D. (2013) Draft report on the food crisis, fraud in the food chain and control thereof (2013/2091 (INI), European Parliament.

Marquetti, I., Link, J.V., Lemes, A.L.G., Scholz, M.B.S., Valderrama, P., Bona, E. (2016) Partial least square with discriminant analysis and near infrared spectroscopy for evaluation of geographic and genotypic origin of arabica coffee. $\begin{array}{llll}\text { Comp } & \text { Electronics } & \text { Agric., } & \text { 313-319. }\end{array}$ https://doi.org/10.1016/j.compag.2015.12.018

Martellossi, C., Taylor, E.J., Lee, D., Graziosi, G., \& Donni, P. (2005) DNA Extraction and Analysis from Processed Coffee Beans. J. Agric. Food Chem., 53 8432-8438. https://doi.org/10.1021/jf050776p

Martin, M.J., Pablos, F., Gonzalez, A.G., Valdenebro, M.S., \& Leon-Camacho, M. (2001) Fatty acid profiles as discriminant parameters for coffee varieties differentiation. Talanta, 54(2), 291-297. https://doi.org/10.1016/S0039 9140(00)00647-0

Martins, V. de C., Godoy, R. L. de O., Gouve^a, A. C. M. S., Santiago, M. C. P. de A., Borguini, R. G., Braga, E. C. de O., et al. (2018). Fraud investigation in commercial coffee by chromatography. Food Quality and Safety, 2(3), 121-133. https://doi.org/10.1093/fqsafe/fyy017

Mehari, B., Redi-Abshiro, M., Chandravanshi, B.S., Combrinck, S., \& McCrindle, R. (2016) Determination of the Geographical Origin of Green Coffee Beans from Ethiopia based on Chemical Composition Profile. Anal. Lett. 49 2474-2489. https://doi.org/10.1080/00032719.2016.1151023

Muñiz-Valencia, R., Jurado, J.M., Ceballos-Magña, S.G., Alcázar, A., \& Hernández-Díaz, J. (2014) Characterization of Mexican coffee according to 
mineral contents by means of multilayer perceptrons artificial neural networks. $J$. Food Comp. Anal., 34, 7-11. https://doi.org/10.1016/j.jfca.2014.02.003

Oliveira, M., Ramos, S., Delerue-Matos, C., \& Morais, S., (2015) Expresso beverages of pure origin coffee: mineral characterization, contribution for mineral intake and geographical origin discrimination. Food Chem., 177, 330338. https://doi.org/10.1016/j.foodchem.2015.01.061

Pauli E.D., Barbieri F., Garcia P.S., Madeira T.B., Acquaro V.R., Scarminio I., da Camara C.A.P., Nixdorf S.L. (2014) Detection of ground roasted coffee adulteration with roasted soybean andwheat. Food Res. Intern., 61, 112-119. https://doi.org/10.1016/j.foodres.2014.02.032

Peixoto, P. Fraudes atingem 25\% das marcas de cafe, diz associac ao. Folha de S ao Paulo, April 2009 . http://www1.folha.uol.com.br/mercado/2009/04/557291-fraudes-atingem-25-dasmarcas-de-cafe-diz-associacao.shtml (accessed 2/9/14).

Pereira, L., Gomes, S., Castro, C., Eiras-Dias, J. E., Braz̃ao, J., Graça, A., et al. (2017). High Resolution Melting (HRM) applied to wine authenticity. Food Chemistry, 216, 80-86. https://doi.org/10.1016/j.foodchem.2016.07.185

Rega F.V., Ferranti P. Life Cycle Assessment of Coffee Production in Time of Global Change. In: Encyclopedia of Food Security and Sustainability [Internet]. Elsevier; 2019, 497-502. Available from: https://doi.org/10.1016/b978-0-08100596-5.22141-0

Romano, R., Santini, A., Le Grottaglie, L., Manzo, N., Visconti, A., \& Ritieni, A. (2014) Identification markers based on fatty acid composition to differentiate between roasted Arabica and Canephora (Robusta) coffee varieties in mixtures. $J$. Food Compos. Anal., 35, 1-9. https://doi.org/10.1016/j.jfca.2014.04.001

Rubayiza, A. B., \& Meurens, M. (2005). Chemical discrimination of arabica and robusta coffees by fourier transform Raman spectroscopy. J. Agric. Food Chem. 2005, 53(12), 4654-4659. https://doi.org/10.1021/jf0478657

Schievano, E., Finotello, C., de Angelis, E., Mammi, S., \& Navarini, L. (2014) Rapid Authentication of Coffee Blends and Quantification of 16-OMethylcafestol in Roasted Coffee Beans by Nuclear Magnetic Resonance. $J$. Agric. Food Chem., 62, 12309-12314. https://doi.org/10.1021/jf505013d

Servillo, L., Giovane, A., Casale, R., Cautela, D., D’Onofrio, N., Balestrieri, M.L., \& Castaldo, D. (2016) Glucosylated forms of serotonin and tryptophan in green coffee beans. Food Chem. 205, 52-57

Sezer, B., Apaydin, H., Bilge, G., \& Boyaci, I. H. (2018). Coffee arabica adulteration: Detection of wheat, corn and chickpea. Food Chemistry, 264(May), 142-148. https://doi.org/10.1016/j.foodchem.2018.05.037

Smith, I.B. (2014) Kopi Luwak Coffee - World's Most Expensive Coffee Beans from Civet Poop or an Urban Myth? Ipact Limited, Ltd, Middlesex, United Kingdom. ISBN $9780992798710.116 \mathrm{p}$.

Speer, K., Kölling-Speer, I. (2006) The lipid fraction of the coffee bean, Braz. J. Plant Physiol. vol. 18, no. 1, 201-216

Tarzia, A., dos Santos Scholz, M.B., de Oliveria Petkowiez, C.L. (2010) Influence of the postharvest processing method on polysaccharides and coffee beverages. Food Sci. Technol., 45, 2167-2175. https://doi.org/10.1111/j.13652621.2010.02388.x

THE LANCET. (1851). The Analytical Sanitary Commission. Coffee and its adulterations. The Lancet, 57: 21-26. https://doi.org/10.1016/S01406736(00)32356-X

Toci, A. T., Farah, A., Pezza, H. R., \& Pezza, L. (2016). Coffee adulteration: More than two decades of research. Crit. Rev. Anal. Chem., 46(2), 83-92. https://doi.org/10.1080/10408347.2014.966185

Tolessa, K., Rademaker, M., Baets, B.D., Boeckx, P. (2016) Prediction of specialty coffee cup quality based on near infrared spectra of green coffee beans. Talanta 150, 367-374. https://doi.org/10.1016/j.talanta.2015.12.039

Trugo, L.C., \& Macrae, R. (1984) A study of the effect of roasting on the chlorogenic acid composition of coffee using HPLC Food Chem vol. 15, no. 3 , 219-227

Valentin, J.L., \& Watling, R.J. (2013) Provenance establishment of coffee using solution ICP-MS and ICP-AES. Food Chem. 141, no. 1, p. 98-104. https://doi.org/10.1016/j.foodchem.2013.02.101

van der Vossen, H., Bertrand, B., \& Charrier, A. (2015). Next generation variety development for sustainable production of arabica coffee (Coffea arabica L.): A review. Euphytica, 204, 243-256. https://doi.org/10.1007/s10681-015-1398-z

Wang, N., Fu, Y., \& Lim, L.T. (2011) Feasibility Study on Chemometric Discrimination of Roasted Arabica Coffees by Solvent Extraction and Fourier Transform Infrared Spectroscopy. J. Agric. Food Chem., 59, 7, p. 3220-3226. https://doi.org/10.1021/jf104980d

Wang, X., Lim, L. T., Fu, Y. (2020). Review of Analytical Methods to Detect Adulteration in Coffee. Journal of AOAC International., 103(2), p. 295-305. https://doi.org/10.1093/jaocint/qsz019

Wermelinger, T., D'Ambrosio, L., Klopprogge, B., Yeretzian, C. (2011) Quantification of the Robusta fraction in a coffee blend via Raman spectroscopy: proof of principle. J. Agric. Food Chem., 59, 9074-9079. https://doi.org/10.1021/jf201918a

Widyastuti, N., Anjani, G., Almira, V. G., Putri, S. E., \& Pratiwi, A. R. (2020). Effects of the administration of brewed Robusta coffee leaves on total antioxidant status in rats with high-fat, high-fructose diet-induced metabolic syndrome.
Potravinarstvo Slovak Journal of Food Sciences, 14, 258-263. https://doi.org/10.5219/1350

Yener, S., Romano, A., Cappellin, L., Granitto, P.M., Aprea, E., Navarini, L., Märk, T.D., Gasperi, F., Biasioli, F. (2015) Tracing coffee origin by direct injection headspace analysis with PTR/SRI-MS. Food Res. Intn., 69, 235-243. https://doi.org/10.1016/j.foodres.2014.12.046 